\title{
Efficiency Examination of Turkish Airports with DEA Approach
}

\author{
Habip Koçak \\ Faculty of Business Administration and Economics, Econometrics Department \\ Marmara University, Campus of Bahçelievler, Istanbul \\ Tel: 90-212- 507-9925 Ext. $1220 \quad$ E-mail:hkocak@marmara.edu.tr
}

Received: October 13, 2010 Accepted: December 8, 2010 doi:10.5539/ibr.v4n2p204

\begin{abstract}
In this paper, 40 airports in Turkey were examined with the help of Data Envelopment Analyze (DEA) Model and it was aimed to measure the activities of year 2008. For this purpose, operation expenses, number of personnel, flight traffic and number of passengers were taken as input variables, whereas number of passengers/area, flight traffic/runway, total load and operation expenses were taken as output variables. The analysis was solved with DEA Solver and it was concluded that the most effective airports were Istanbul Atatürk, Antalya, Denizli Çardak, Sinop, Kayseri Malatya and Van F.Melen Airports.
\end{abstract}

Keywords: Effectiveness, DEA, Airports

\section{Introduction}

Air transport industry is one of the most important industries of the world. It began to manifest itself at the beginning of the $20^{\text {th }}$ century, and continued its development rapidly after technical improvements in particular. The development as well as achievements in technique and services in air transport is the most critical auxiliary in the progress of modern societies. After the flight of the first jet engine plane in 1949, commercial air transport grew more than 70 times. This unmatched growth has been the basic factor of economic development.

Air transport industry, which is one of the industries that has made great contribution to economic and social development of societies, has a very dynamic structure. The fast, safe and cushioned transportation that it provides increases the demand for its services on a daily basis; along with developed economic and social changes, privatization, commercialization, and liberalization have affected not only the air transport system but also the airports, which is its the most important element. As service industry investments, airports do not just meet transportation needs within these understandings; they have turned into investments that make business and generate income within the framework of their service range, and serve in a competitive environment with the awareness of the benefits that being an important transfer centre in the international transport network would bring. The best way for these investments to go forward in this change is to monitor their own performance and compare it with those of similar airports.

An examination of the studies on airports about performance and efficiency reveals that the most widely used technique was Data Envelopment Analysis (DEA) and effectiveness of 40 Turkish airports for the year 2008 was measured with input-oriented DEA method.

\section{Effectiveness and Efficiency Measurements}

Effectiveness and efficiency are among the most important concepts that establish the foundations of modern management philosophy. However, when several problem areas related to the evaluation of management process are taken into account, in most cases measuring performance becomes harder due to the lack of reliable and valid measurement techniques that have become standardized. It is even more difficult in the service industry compared to manufacturing industry as it includes hard-to-measure outputs such as service quality and customer satisfaction.

Today performance concept is gaining importance in especially the services industry. In most general terms, operation performance can be defined as the rate of success obtained by a business in a given period of time. In other words, performance is the qualitative and quantitative expression of the point reached by an individual, group or enterprise as measured against the inputs used for the aimed target. DEA, which is a method without parameter, is the most frequently used effectiveness measurement method; it is a technique with linear-programming base which aims to measure the relative performance of decision-making units. DEA determines the situation of the rate of mathematical total weighted outputs to mathematical total weighted inputs in terms of unit efficiency against the 
limit which represents best performance. This approach was first developed by Farrel and then improved by Farrel and Fieldhouse.

\section{Review of Literature}

The issue of measuring and improving performance at airports has attracted the attention of several researchers in the world. Quite a lot of studies exist in this area.

In their study dated 1997, Gillen and Lall evaluated efficiency and performance using the data of 21 USA airports belonging to years 1989 to 1992 . Terminal effectiveness has 6 inputs, namely number of runways, number of gates, terminal area, number of employees, number of baggage conveyors and passenger parking area, and 2 outputs, namely number of passengers and size of cargo in tons. In addition, 4 inputs, namely the airport area, number of runways, area of runways and number of employees, and 2 outputs, namely air transport activities and direction activities were handled in order to measure the performance of activities at airports. An output-oriented system was used in the study and effort was made to explain the changes between airports depending on time in performance.

Martin and Roman (2001) used data envelopment method in order to evaluate the performance of Spanish airports before privatization. Based on 1997 data 37 airports in the country were assessed. In the article, the inputs were given as expenses related to workmanship, capital and material, whereas air transport activities, number of passengers and size of cargo in tons were given as the outputs. Number of runways, number of gates, terminal area and number of employees were not used due to insufficient data. In effectiveness evaluation process, it is also important to examine how effectiveness developed in time. For this purpose, Malmquist Total Factor Effectiveness index, which includes time dimension, was developed. This index is used for measuring efficiency in time. Melchor and Carmen (1999) examined airport effectiveness in Spain with Malmquist index.

Francis et al. (2002) examined 200 airports in their study and investigated the validity and structure of applications in airports with the help of a survey applied to managers. Humphreys and Francis (2002) examined the changing structure of airport performance indicators so as to measure the current and future airport performance.

Pels et al. (2001) used DEA to examine air transport activities and passenger activities by determining the relative effectiveness of European airports between 1995 and 1997. Pels et al. (2003) investigated the inefficiency and scale economies in operation of European airports. In their article, physical capacity data were also included, but it was stated that environment-related capacity data and delay in schedule data were not available and therefore used.

Adler and Berechman (2001) developed a model so as to determine the relative effectiveness and quality of airports. In the literature, previous studies used subjective data of passengers, whereas this study ued definitions made by airways. In evaluation part of the study it was concluded that average of statistical analysis was a function of quality factors and airports. In this study, DEA and basic components analysis method was used so as to determine the relative quality level of airports. Fernandes and Pacheco (2002) aimed to obtain maximum output with their BCC model. The researchers examined 35 airports in Brazil and defined the inputs as apron area, exit area, number of entry check points, limitation façade, number of vehicle parking lots and baggage declaration, whereas the only output was defined as number of domestic terminal passengers both on and off board. In the study potential demand estimations were also made for the years 2002, 2007 and 2017. Different scenarios were derived and interpretations were made as to how effectiveness would be affected.

Pacheco and Fernandes (2003) conducted a study which handled managerial and physical dimensions so as to evaluate the 1998 performance of 35 local Brazilian airports. Researchers used BCC model in data envelopment analysis and tried to minimize inputs. The 3 inputs were determined as average number of employees, payrolls including direct and indirect benefits and operation expenses, and the 5 outputs were identified as number of domestic terminal passengers, number of cargo and mails, operation revenues, commercial revenues and financial and other revenues. In addition, a comparison was made with the conclusions of the previous study.

Bazargan and Vasigh (2003) evaluated 45 USA airports using CCR method. The inputs were operation expenses, non-operation expenses, number of runways and number of gates whereas the outputs were taken as number of passengers, number of air transport activities, number of other activities, aviation revenues, non-aviation revenues, and percentage of timely operations.

Holvard and Graham (2004) examined the British airports with data envelopment analysis method. Oum et al. (2002) compared 50 major airports in Asia, Pacific, Europe and North America in terms of their productive efficiencies by first calculating Total Efficiency Factor (TEF), then analyzing the TEF with regression models and finally by subtracting the factors which were not under control of the management. According to the results of this study, major airports are expected to obtain higher TEF values due to their economic indicators in aviation operations; 
however, this does not mean that they are more effective than smaller airports. It is expected that airports with higher international traffic percentage will have lower TEF values.

A study on Taiwan measured physical effectiveness of 14 local airports in the case of existence of environmental impacts and unwanted outputs $(\mathrm{Yu}, 2004)$. The study was designed as output-oriented and covers managerial and physical values. In this model inputs were determined as runway area, apron area, terminal area and number of routes of each airport. The outputs were defined as the number of flight traffic activities, number of passengers and, as an unwanted factor, the noise produced by planes.

Based on the data of 5 years, Sarkis and Talluri (2004) evaluated the performance of 44 airports in the USA using multi-criteria non-parametric models. The inputs of this study were airport operation expenses, number of employees in the airport, number of gates and runways. The outputs were operational revenues (parking fees, landing fees, user fees, commercial development revenues and charter revenues), passenger flow, commercial aviation activities and total cargo transfer. In this study results were obtained according to CCR and BCC effectiveness scores and interpreted. It was concluded that studies in the future would yield more realistic results by taking into consideration the impact of weather conditions and/or privatization.

A study conducted on 67 Japanese airports with data of year 2000 aimed at measuring input-based effectiveness (Yoshida and Fujimoto, 2004). The inputs in this study were the length of runway, size of terminal, transport expenses and number of employees, whereas the outputs were passenger density, cargo carriage, and flight activities. In this study it was concluded that airports with bigger terminals and less users had lower effectiveness scores.

This literature search found out that the first study which used data enveloping method for evaluating the performance of Turkish airports was conducted by Düzakın and Güçray (2001). The authors examined the privatization of the biggest and state-run airway company of the country. They emphasized that operational effectiveness of airports would be important for potential buyers and mentioned that it would be necessary to reorganize airports for this purpose. Kıyıldı and Karaşahin (2006) evaluated with DEA 32 airports which gave civilian air transport services. From the infrastructure data obtained for airports, the variables which would best reflect the infrastructure utilization capacity of airport were chosen (namely number of planes, number of aprons, number of X-ray devices and terminal usage area) and CCR model was applied; as a result, relative performance values and efficiency levels of airports were determined.

In their study in 2009, Peker and Baki (2009) examined airport effectiveness in 2007 using DEA. In this study 4 inputs and 2 outputs were employed and 5 of 14 major airports and 2 of 23 small airports were found as "effective".

Performance evaluation of Turkish airports according to their financial values was examined in a master's thesis (Kuyucak, 2001). Moving from the input-output charts of airports, defined ratios were examined and interpretations were made on which airports would provide the best investment opportunities.

\section{Methodology of The Study}

\subsection{Purpose of the Study}

The basic purpose of this study is to measure the 2008 effectiveness of 40 airports in Turkey. In addition, another purpose is to calculate the extent to which inputs would be decreased or outputs would be increased so that the airports which are not or cannot be effective can reach the effectiveness limits.

\subsection{Method Employed in this Study}

In an intense and chaotic competitive environment, firms have to measure their effectiveness levels so that they can see their present situation in the industry and create a more effective management by estimating the future. Measurements show how efficient the firms use their resources and give them the opportunity to evaluate their competitive positions compared to their competitors. Such measures as effectiveness, efficiency, profitability and growth are used in evaluation of organizational performance.

CCR model is the first ad basic DEA model developed by Charnes, Cooper and Rhodes (1978) based on the idea of effectiveness. CCR calculates total effectiveness by accumulating the technical effectiveness and scale effectiveness of a unit in a single value. Although other models were developed, CCR is still the most widely used and recognized model. CCR model, which aims at output maximization, is given below:

$$
\begin{aligned}
& \text { Objective function } \quad M a k \mathrm{~h}_{k}=\sum_{r=1}^{s} u_{r k} Y_{r k} \quad 1 \leq k \leq m, \mathrm{k} \in R \\
& \text { Constraints } \\
& \qquad \sum_{r=1}^{s} u_{r k} Y_{r j}-\sum_{i=1}^{m} v_{i k} X_{i j} \leq 0 \quad \mathrm{j}=1,2, \ldots, \mathrm{N}
\end{aligned}
$$




$$
\begin{aligned}
& \sum_{i=1}^{m} v_{i k} X_{i k}=1 \\
& u_{r k}, v_{i k} \geq \varepsilon \quad \mathrm{r}=1,2, \ldots, \mathrm{s} \quad \mathrm{i}=1,2, \ldots, \mathrm{m} \\
& h_{k}: \text { effectiveness of decision unit } \mathrm{k} \\
& u_{r k}: \text { weight of decision unit } \mathrm{k} \text { for outputs } \mathrm{r} \\
& v_{i k}: \text { weight of decision unit } \mathrm{k} \text { for inputs } \mathrm{i} \\
& Y_{r k}: \text { r.output value of decision unit } \mathrm{k} \\
& X_{i k}: \text { i.input value of decision unit } \mathrm{k} \\
& Y_{r j}: \text { r.output value of decision unit } \mathrm{j} \\
& X_{i j}: \text { i.input value of decision unit } \mathrm{j} \\
& \varepsilon: \text { a numeric value very close to zero }
\end{aligned}
$$

BCC model was developed by Banker, Charnes and Cooper (1984) and measures technical effectiveness under the assumption that revenue varies according to scale. If the revenue is stable according to scale, a comparison of effectiveness reveals a situation with lower performance, as the decision-making unit has to have both technical and scale effectiveness so as to reach 1 effectiveness value. In case of revenue varying according to scale, a unit with no scale effectiveness can be above the effectiveness limit as "the best observation" if it has technical effectiveness. As a result, it can be said that for the same decision-making unit, technical effectiveness measure is lower at stable revenue case than at varying-according-to-scale case. BCC model, which aims at input minimization, is given below:

Objective function

$$
\text { Mak } \mathrm{h}_{k}=\sum_{r=1}^{s} u_{r k} Y_{r k}-u_{0} \quad 1 \leq k \leq m, \mathrm{k} \in R
$$

Constraints

$$
\sum_{r=1}^{s} u_{r k} Y_{r j}-u_{0}-\sum_{i=1}^{m} v_{i k} X_{i j} \leq 0 \quad \mathrm{j}=1,2, \ldots, \mathrm{N}
$$

$$
\begin{aligned}
& \sum_{i=1}^{m} v_{i k} X_{i k}=1 \\
& u_{r k}, v_{i k} \geq \varepsilon \quad \mathrm{r}=1,2, \ldots, \mathrm{s} \quad \mathrm{i}=1,2, \ldots, \mathrm{m}
\end{aligned}
$$

CCR model measures total effectiveness under stable revenue assumption, whereas $\mathrm{BCC}$ model measures technical effectiveness by comparing units with similar scales based on the assumption that revenue varies according to scale. In this case effectiveness (E) is expressed as below:

$$
E_{C C R}=E_{\text {Scale }} * E_{B C C}
$$

\subsection{Scope of the Study and Variables}

In order to be able to apply DEA, decision-making units should be chosen, inputs and outputs should be determined, effectiveness values should be found and obtained results should be evaluated.

The study took the year 2008 as examination period. It was aimed to find the effectiveness of airports and potential changes in effectiveness in this period. Forty airports in Turkey were taken as decision-making units, which are shown in Annex-1. Data belonging to decision-making units were obtained from the web site of Directorate General of State Airfields. However, the airports in Turkey can be grouped into categories as big airports, which have annual 50.000 and above passenger capacity, and small airports, which have annual passenger capacity below 50.000 . In this study all airports were examined under the same category as they were evaluated under common inputs and outputs, but the analytical findings were also evaluated separately.

Insert Table 1 here

Determination of inputs and outputs belonging to the decision-making units which will be used in the analysis is highly important, as changing the chosen inputs and outputs causes differentiation in effectiveness scores. Several decision-making units might not be effective in other studies. Minimum decision-making unit recommended by Banker should be at least 3 times of the total number of inputs and outputs. In this study 4 input and 4 output 
variables will be used and the data of 40 airports will be used as decision-making units. Table 1 gives the details of inputs and outputs used in this study.

Insert Table 2 here

In this model, when variables were chosen those variables which had the most appropriate correlations among available data were determined. It was preferred to leave out those input variables which were strongly correlated with each other and output variables. Table 3 gives correlation matrix of variables and table 4 provides the definitive statistics of these variables.

Insert Table 3 here

When the correlation matrix is examined, it can be seen that flight traffic variable, which is an input variable, is strongly correlated with output variables. Linear relation with flight traffic/runway variable was 0.9665 , with total cargo was 0.9553 and operational revenues was 0.9720 ; likewise, the number of passengers variable reveals 0.9401 , 0.9738 and 0.9874 linear relation with flight traffic/runway, total cargo and operational revenues, respectively. Input and output variables did not reveal important correlation in their own groups, either.

Insert Table 4 here

\subsection{Analytical Results and Evaluation}

Input-oriented DEA effectiveness figures for airports obtained by DEAP V.2.1 program are given in table 5 below. CCR models give total effectiveness values and BCC models give technical effectiveness. Technically-effective decision-making units show that, within the available technology and technological change, maximum output is obtained by using a given input combination or a given output combination is produced by using minimum inputs. If a technically-effective decision-making unit suffers from ineffectiveness caused by scale, the total result turns out as ineffectiveness as well.

Insert Table 5 here

As a result of the analysis, it can be seen that İstanbul Atatürk, Antalya, Denizli Çardak, Sinop, Kayseri, Malatya and Van Ferit Melen airports are effective. Compared with previous studies in this area, it has been observed that İstanbul Atatürk, Kayseri and Antalya airports were found as effective airports. In addition, Peker and Baki found Malatya and Denizli Çardak as effective airports. Adana and Trabzon airports are technically effective but they are not operated at proper scale which results in total ineffectiveness.

It can be seen that Ağr1 and Isparta S.Demirel airports are operated at proper scale but are technically ineffective, which means that heir resources are not effectively employed. It can be understood that Balıkesir, Merzifon and Uşak airports are neither operated at proper scale nor they can use their resources effectively.

Ankara Esenboğa, İzmir A.Menderes, Erzurum, Gaziantep, Diyarbakır and Erzurum airports and Bursa Yenişehir, Çanakkale, Elazı $\breve{g}$, Konya and Mardin airports are operated at proper scale but they cannot make effective use of their resources; thus, although they come close to technical effectiveness, they cannot be totally effective.

When potential improvements are examined, this gives the decrease needed in inputs (or the increase in outputs) by ineffective airports in order to reach effectiveness limit, it can be seen that effectiveness score of, say, Gaziantep aerodrome is 0.87 , flight traffic idleness value is 17.56 and personnel number idleness value is 9.34 . Accordingly, this airport will be effective if it increases flight traffic by $17.56 \%$ and decrease personnel number by $9.34 \%$.

\section{Conclusion}

The increase in the number of airway companies as well as the comfort and time-saving in air transport made airport business an attractive one. For developing countries like ours whose resources are limited, effective operation of airports which cost lots of money is highly important, as airports have to be operated effectively so as to make it a profitable business. For this purpose, efficiency of airports should be controlled by making capacity usage analysis in regular intervals and new operation strategies should be adopted according to the obtained results.

Airports constitute the most complicated part of air transport system; they are the places where interest groups which are interacted with each other come together physically. As air transport provides fast, reliable and comfortable travel, people prefer air transport more and number of passengers increase on a daily basis. It is impossible for the airports to respond to this increase by renewing their infrastructure at the same pace. For this reason, performances of physical and workforce infrastructures required to meet the expectations of passengers should be monitored with "continuous improvement" philosophy so that current capacities of airports can be utilized at maximum level and users can obtained better service at higher quality. Performance of airports must be compared not only with their past performance but also with the performance of similar airports. Future studies might 
concentrate on examination of the change in effectiveness of all airports in years and compassion of international airports with similar characteristics.

\section{References}

ATAG. (2005). The Economic and Social Benefits of Air Transport, [Online], Available at: http://www.atag.org/files/Soceconomic-121116A.pdf, (Accessed: 10 June 2010).

Banker R.D. (1992). Estimation of Returns to Scale Using Data Envelopment Analysis, European Journal of Operations Research, 62, pp. 74-84.

Bazargan M. and Vasigh B. (2003). Size Versus Efficiency: A Case Study of US Commercial Airports, Journal of Air Transport Management, Volume 9, Issue 3, pp.187-193

Boussofiane A., Dyson R. and Rhodes E. (1991). Applied Data Envelopment Analysis, European Journal of Operational Research, Volume 2, Issue 6, pp. 1-15.

Cooper W.W., Seiford M.L. and Tone K. (2000). Data Envelopment Analysis, New York: Kluwer Academic Publishers

Düzakın E, \& Gucray A. (2001). An Analysis of The Efficiency of Airports in Turkey. (OR 43) 43th Annual Conference of the Operational Research Society Abstracts, Bath, United Kingdom, 9/4 to 9/6.

Gattoufi S., Oral M.,Reisman A. (2002). Data Envelopment Analysis Literature: A Bibliography Update (1951-2001).[Online], Available at: http://bilmer.sabanciuniv.edu/elit/gsm/sugsm02_08.pdf (Accessed: 22 July 2010)

Gillen D., \& Lall A. (1997). Developing Measures of Airport Productivity and Performance: An Application of Data Envelopment Analysis, Transportation Research Part E: Logistics and Transportation Review, 33(4). pp.261-273.

Holvad T. and Graham A. (1997). Efficiency Variations for European and Australian Airports, 39th Annual Conference of the Operational Research Society, Bath, United Kingdom, 9/9 to 9/11.

Humphreys I. and Francis G. (2002). Performance Measurement: A Review of Airports, International Journal of Transport Management, Volume 1, Issue 2, pp.79-85

Kocakalay S. and Isık A. (2003). Data Envelopment Analysis, Journal of Institute of Science and Technology, University of Dumlupinar, Issues 5, pp.163-171.

Kuyucak F. (2001). Performance Analysis of Airports in Turkey and Suggest a model for Airports in Turkey, Journal of the Institute of Social Sciences, University of Anadolu, p.161.

Martín C.J. \& Román C. (2001). An Application of DEA to Measure The Efficiency of Spanish Airports Prior to Privatization, Journal of Air Transport Management, 7(3). pp.149-157.

Pacheco R. R. \& Fernandes E. (2003). Managerial Efficiency of Brazilian Airports, Transportation Research Part A: Policy and Practice, 37(8). pp.667-680.

Peker I. and Baki B. (2009). Application of Data Envelopment Analysis of the Relative Efficiency and Turkey Airports, Journal of the Institute of Social Sciences, University of Çukurova, Volume 18, Issues 2, pp. 72-88

Sarkis J. (2000). An Analysis of the Operational Efficiency of Major Airports in the United States, Journal of Operations Management, 18(3). pp.335-351.

Sarkis J., \& Talluri S. (2004). Performance Based Clustering for Benchmarking of US airports, Transportation Research Part A: Policy and Practice, 38(5). pp.329-346.

Web site of Devlet Hava Meydanları Isletmesi, [Online], Avaliable at: http://www.dhmi.gov.tr. (Accessed: 15 July 2010) 
Table 1. Big and Small Airports Used In The Analysis

\begin{tabular}{|l|l|}
\hline \multicolumn{1}{|c|}{ Big Airports } & \multicolumn{1}{|c|}{ Small Airports } \\
\hline İstanbul Atatürk* & Adıyaman \\
Ankara Esenboğa & Ağrı \\
İzmir A.Menderes & Balıkesir \\
Antalya & Bursa Yenişehir \\
Adana & Çanakkale \\
Kayseri & Denizli Çardak \\
Trabzon & Elazı̆ \\
Van F.Melen & Erzincan \\
Diyarbakır & Gaziantep \\
Muğla Dalaman & Hatay \\
Erzurum & Isparta S.Demirel \\
Samsun Çarşamba & K.Maraş \\
Milas Bodrum & Kars \\
Malatya & Konya \\
& Körfez \\
& Mardin \\
& Merzifon \\
& Muş \\
& Nevşehir Kapadokya \\
& Siirt \\
& Sinop \\
& Sivas \\
& Şanlıurfa \\
& Tekirdağ Çorlu \\
& Tokat \\
& Uşak \\
\hline
\end{tabular}

*: İstanbul Sabiha Gökçen Airport was excluded from analysis as its data were problematic.

Table 2. Definition of Inputs and Outputs

\begin{tabular}{|l|l|}
\hline Inputs & Details \\
\hline Operational expenses & $\begin{array}{l}\text { Total expenses made on materials, personnel, benefit services, taxes, duties and depreciation by airports } \\
\text { in one year }\end{array}$ \\
\hline Number of personnel & Number of people employed in an airport in one year \\
\hline Annual flight traffic & Maximum number of planes that airports can serve in one year \\
\hline Number of passengers & Number of passengers that airports can serve in one year \\
\hline Outputs & Details \\
\hline Number of passengers/area & $\begin{array}{l}\text { The annual number of passengers per each square meter was found after calculating the areas open to } \\
\text { passengers in the airport }\end{array}$ \\
\hline Total flight traffic/runway & Total weight of cargoes, mails and baggage carried at the aerodrome in one year \\
\hline Total cargo traffic & Amount of total flight traffic per number of runways at the airport throughout the year \\
\hline Operational revenues & $\begin{array}{l}\text { Total revenues obtained from airway companies in exchange of the air travel and terminal services } \\
\text { provided by the airport throughout the year. }\end{array}$ \\
\hline
\end{tabular}

Table 3. Correlation Matrix

\begin{tabular}{|c|c|c|c|c|c|c|c|c|}
\hline & $\begin{array}{c}\text { Operational } \\
\text { expenses }\end{array}$ & $\begin{array}{c}\text { Number of } \\
\text { personnel }\end{array}$ & $\begin{array}{l}\text { Flight } \\
\text { traffic }\end{array}$ & $\begin{array}{l}\text { Number of } \\
\text { passengers }\end{array}$ & $\begin{array}{c}\text { Number of } \\
\text { passengers/ } \\
\text { area } \\
\end{array}$ & $\begin{array}{c}\text { Flight } \\
\text { traffic/ } \\
\text { runway }\end{array}$ & $\begin{array}{l}\text { Total } \\
\text { cargo }\end{array}$ & $\begin{array}{c}\text { Operational } \\
\text { revenues }\end{array}$ \\
\hline Operational expenses & 1.0000 & & & & & & & \\
\hline Number of personnel & 0.7524 & 1.0000 & & & & & & \\
\hline Flight traffic & 0.6829 & 0.7498 & 1.0000 & & & & & \\
\hline Number of passengers & 0.8778 & 0.7291 & 0.8570 & 1.0000 & & & & \\
\hline $\begin{array}{l}\text { Number of } \\
\text { passengers/area } \\
\end{array}$ & 0.1263 & 0.2124 & 0.1521 & 0.1329 & 1.0000 & & & \\
\hline Flight traffic/runway & 0.7234 & 0.8146 & 0.9665 & 0.9401 & 0.2178 & 1.0000 & & \\
\hline Total cargo & 0.5201 & 0.7863 & 0.9553 & 0.9738 & 0.3856 & 0.9335 & 1.0000 & \\
\hline Operational revenues & 0.8103 & 0.8495 & 0.9720 & 0.9874 & 0.4547 & 0.8485 & 0.9296 & 1.0000 \\
\hline
\end{tabular}


Table 4. Definitive Statistics for Turkish Airports

\begin{tabular}{|l|c|c|c|c|c|c|c|c|}
\hline & \multicolumn{3}{|c|}{ Inputs } & \multicolumn{3}{c|}{ Outputs } \\
\hline Definition & $\begin{array}{c}\text { Operational } \\
\text { expenses }\end{array}$ & $\begin{array}{c}\text { Number of } \\
\text { personnel }\end{array}$ & $\begin{array}{c}\text { Flight } \\
\text { traffic }\end{array}$ & $\begin{array}{c}\text { Number of } \\
\text { passengers }\end{array}$ & $\begin{array}{c}\text { Number of } \\
\text { passengers/area }\end{array}$ & $\begin{array}{c}\text { Flight traffic/ } \\
\text { runway }\end{array}$ & $\begin{array}{c}\text { Total } \\
\text { cargo }\end{array}$ & $\begin{array}{c}\text { Operational } \\
\text { revenues }\end{array}$ \\
\hline Average & $12.574,84615$ & 169,4359 & $17.588,79$ & 1.922 .265 & 141,4941 & $8.672,653846$ & $39.349,20513$ & $30.578,51282$ \\
\hline $\begin{array}{l}\text { Standard } \\
\text { deviation }\end{array}$ & $17.871,65644$ & 237,2546 & $48.609,35$ & 5.417 .161 & 118,8728 & $16.967,75151$ & $137.084,9065$ & $106.490,9948$ \\
\hline The highest & 83.241 & 1.115 & 276.148 & 28.553 .132 & 443,0226 & $92.049,33333$ & 783.209 & 581.060 \\
\hline The lowest & 1.077 & 22 & 97 & 6882 & 3,208392 & 97 & 127 & 32 \\
\hline
\end{tabular}

Table 5. Effectiveness Scores of Turkish Airports

\begin{tabular}{|c|c|c|c|}
\hline AIRPORTS & CCR & BCR & SCALE EFFECTIVENESS \\
\hline Adana & 0,85 & 1,00 & 0,97 \\
\hline Adryaman & 0,31 & 0,45 & 0,69 \\
\hline Ăgr1 & 0,26 & 0,26 & 1,00 \\
\hline Ankara Esenboğa & 0,93 & 0,96 & 0,97 \\
\hline Antalya & 1,00 & 1,00 & 1,00 \\
\hline Balıkesir & 0,10 & 0,28 & 0,36 \\
\hline Bursa Yenişehir & 0,75 & 0,83 & 0,90 \\
\hline Çanakkale & 0,65 & 0,69 & 0,94 \\
\hline Denizli Çardak & 1,00 & 1,00 & 1,00 \\
\hline Diyarbakır & 0,85 & 0,87 & 0,98 \\
\hline Elazı ̆ & 0,58 & 0,62 & 0,94 \\
\hline Erzincan & 0,32 & 0,39 & 0,82 \\
\hline Erzurum & 0,74 & 0,76 & 0,97 \\
\hline Gaziantep & 0,87 & 0,90 & 0,97 \\
\hline Hatay & 0,38 & 0,43 & 0,88 \\
\hline Isparta S.Demirel & 0,45 & 0,45 & 1,00 \\
\hline İstanbul Atatürk & 1,00 & 1,00 & 1,00 \\
\hline İzmir A. Menderes & 0,85 & 0,93 & 0,91 \\
\hline K.Maraş & 0,45 & 0,56 & 0,80 \\
\hline Kars & 0,53 & 0,59 & 0,90 \\
\hline Kayseri & 1,00 & 1,00 & 1,00 \\
\hline Konya & 0,65 & 0,68 & 0,96 \\
\hline Körfez & 0,20 & 0,33 & 0,61 \\
\hline Malatya & 1,00 & 1,00 & 0,95 \\
\hline Mardin & 0,83 & 0,88 & 0,94 \\
\hline Merzifon & 0,17 & 0,29 & 0,59 \\
\hline Milas Bodrum & 0,65 & 0,66 & 0,98 \\
\hline Muğla Dalaman & 0,59 & 0,78 & 0,76 \\
\hline Muş & 0,23 & 0,35 & 0,66 \\
\hline Nevşehir Kapadokya & 0,16 & 0,22 & 0,73 \\
\hline Samsun Çarşamba & 0,73 & 0,75 & 0,97 \\
\hline Siirt & 0,32 & 0,40 & 0,80 \\
\hline Sinop & 1,00 & 1,00 & 1,00 \\
\hline Sivas & 0,58 & 0,66 & 0,88 \\
\hline Şanlıurfa & 0,60 & 0,61 & 0,98 \\
\hline Tekirdağ Çorlu & 0,68 & 0,69 & 0,99 \\
\hline Tokat & 0,35 & 0,43 & 0,81 \\
\hline Trabzon & 0,92 & 1,00 & 0,96 \\
\hline Uşak & 0,19 & 0,22 & 0,86 \\
\hline Van Ferit Melen & 1,00 & 1,00 & 1,00 \\
\hline
\end{tabular}


Annex-1: Data Set of Model

\begin{tabular}{|c|c|c|c|c|c|c|c|c|}
\hline Airport & $\begin{array}{c}\text { Operational } \\
\text { expenses }\end{array}$ & $\begin{array}{c}\text { Number of } \\
\text { personnel }\end{array}$ & $\begin{array}{l}\text { Flight } \\
\text { traffic }\end{array}$ & $\begin{array}{l}\text { Number of } \\
\text { passengers }\end{array}$ & \begin{tabular}{|c} 
Number of \\
passengers/ \\
area
\end{tabular} & $\begin{array}{c}\text { Flight } \\
\text { traffic/ } \\
\text { runway }\end{array}$ & $\begin{array}{l}\text { Total } \\
\text { cargo }\end{array}$ & $\begin{array}{c}\text { Operational } \\
\text { revenues }\end{array}$ \\
\hline Adana & 19.105 & 352 & 26.269 & 2.290 .427 & 443 & 26.269 & 32.855 & 18.210 \\
\hline Adiyaman & 2.511 & 48 & 916 & 86.280 & 144 & 916 & 786 & 258 \\
\hline Ağr1 & 3.015 & 54 & 649 & 60.360 & 132 & 649 & 680 & 203 \\
\hline Ankara Esenboğa & 60.333 & 1.115 & 62.859 & 5.692 .133 & 70 & 31.430 & 72.887 & 40.141 \\
\hline Antalya & 49.625 & 527 & 128.753 & 18.789 .257 & 161 & 42.918 & 380.360 & 345.560 \\
\hline Balıkesir & 1.077 & 22 & 97 & 17.399 & 116 & 97 & 153 & 141 \\
\hline Bursa Yenişehir & 10.224 & 107 & 2.120 & 75.462 & 13 & 1.060 & 925 & 475 \\
\hline Çanakkale & 2.389 & 41 & 1.214 & 21.259 & 29 & 1.214 & 167 & 181 \\
\hline Denizli Çardak & 6.451 & 71 & 1.713 & 157.361 & 24 & 1.713 & 1.131 & 980 \\
\hline Diyarbakır & 6.749 & 98 & 7.649 & 967.088 & 361 & 7.649 & 10.141 & 4.578 \\
\hline Elazığ & 5.352 & 106 & 1.588 & 135.293 & 223 & 1.588 & 1.655 & 563 \\
\hline Erzincan & 5.525 & 56 & 1.490 & 91.540 & 115 & 1.490 & 1.100 & 451 \\
\hline Erzurum & 10.489 & 153 & 4.842 & 527.598 & 92 & 2.421 & 5.492 & 283 \\
\hline Gaziantep & 16.087 & 177 & 7.116 & 754.968 & 198 & 3.558 & 8.012 & 3.391 \\
\hline Hatay & 5.117 & 37 & 1.470 & 162.128 & 360 & 1.470 & 1.841 & 492 \\
\hline Isparta S.Demirel & 4.362 & 70 & 1.654 & 15.053 & 11 & 1.654 & 265 & 381 \\
\hline İstanbul Atatürk & 83.241 & 858 & 276.148 & 28.553 .132 & 227 & 92.049 & 783.209 & 581.060 \\
\hline İzmir A. Menderes & 49.082 & 637 & 52.014 & 5.455 .298 & 92 & 26.007 & 75.377 & 53.410 \\
\hline K.Maraş & 3.580 & 60 & 1.002 & 68.167 & 126 & 1.002 & 721 & 153 \\
\hline Kars & 6.243 & 70 & 2.292 & 269.095 & 159 & 2.292 & 3.317 & 889 \\
\hline Kayseri & 7.189 & 79 & 6.358 & 674.833 & 137 & 6.358 & 11.055 & 7.074 \\
\hline Konya & 5.196 & 85 & 2.646 & 266.143 & 101 & 1.323 & 2.973 & 1.717 \\
\hline Körfez & 2.246 & 48 & 780 & 120.000 & 121 & 85 & 153 & 141 \\
\hline Malatya & 5.140 & 68 & 4.102 & 463.817 & 436 & 4.102 & 5.506 & 2.022 \\
\hline Mardin & 4.142 & 32 & 1.662 & 192.764 & 262 & 1.662 & 2.140 & 438 \\
\hline Merzifon & 1.142 & 25 & 170 & 13.888 & 30 & 170 & 127 & 33 \\
\hline Milas Bodrum & 23.859 & 287 & 22.312 & 2.749 .788 & 246 & 22.312 & 36.991 & 56.003 \\
\hline Muğla Dalaman & 20.260 & 349 & 23.188 & 3.208 .668 & 89 & 11.594 & 44.700 & 46.244 \\
\hline Muş & 2.919 & 35 & 806 & 88.875 & 109 & 403 & 939 & 406 \\
\hline Nevşehir Kapadokya & 7.964 & 137 & 1.709 & 100.762 & 40 & 1.709 & 1.320 & 5.691 \\
\hline Samsun Çarşamba & 10.059 & 189 & 5.499 & 604.387 & 128 & 5.499 & 7.017 & 5.048 \\
\hline Siirt & 2.119 & 41 & 346 & 12.581 & 35 & 346 & 149 & 148 \\
\hline Sinop & 1.077 & 29 & 205 & 14.464 & 24 & 205 & 156 & 32 \\
\hline Sivas & 4.613 & 50 & 1.352 & 124.357 & 179 & 1.352 & 1.361 & 482 \\
\hline Şanlıurfa & 9.746 & 89 & 1.474 & 154.657 & 33 & 1.474 & 1.419 & 762 \\
\hline Tekirdağ Çorlu & 6.423 & 77 & 11.201 & 6.882 & 3 & 11.201 & 14.339 & 980 \\
\hline Tokat & 2.530 & 43 & 321 & 21.828 & 60 & 321 & 227 & 63 \\
\hline Trabzon & 16.142 & 214 & 14.688 & 1.469 .713 & 125 & 14.688 & 16.591 & 11.368 \\
\hline Uşak & 2.543 & 36 & 432 & 25.305 & 32 & 432 & 201 & 101 \\
\hline Van Ferit Melen & 6.799 & 84 & 5.637 & 585.319 & 353 & 5.637 & 6.334 & 2.150 \\
\hline
\end{tabular}

